Shewbridge, Scott E.; Perri, Juan; Mineart, Philip; Millet, Richard; Huang, Wilbur; Vargas, Juan; Inamine, Mike; Mahnke, Steve

Levee Erosion Prediction Equations Calibrated with Laboratory Testing

Verfügbar unter / Available at:

https://hdl.handle.net/20.500.11970/100307

Vorgeschlagene Zitierweise / Suggested citation:

Shewbridge, Scott E.; Perri, Juan; Mineart, Philip; Millet, Richard; Huang, Wilbur; Vargas, Juan; Inamine, Mike; Mahnke, Steve (2010): Levee Erosion Prediction Equations Calibrated with Laboratory Testing. In: Burns, Susan E.; Bhatia, Shobha K.; Avila, Catherine M. C.; Hunt, Beatrice E. (Hg.): Proceedings 5th International Conference on Scour and Erosion (ICSE-5), November 7-10, 2010, San Francisco, USA. Reston, Va.: American Society of Civil Engineers. S. 293-304. 


\section{Levee Erosion Prediction Equations Calibrated with Laboratory Testing}

Scott Shewbridge ${ }^{1}$ M. ASCE, Juan Perri ${ }^{1}$ M. ASCE, Philip Mineart ${ }^{1}$ M. ASCE, Richard Millet ${ }^{2}$ M. ASCE, Wilbur Huang ${ }^{2}$ M. ASCE, Juan Vargas ${ }^{2}$ M. ASCE, Mike Inamine $^{3}$ M. ASCE, and Steve Mahnke ${ }^{3}$ M. ASCE,

${ }^{1}$ URS Corporation URS Corporation, 1333 Broadway, Suite 800, Oakland, CA 94612,email: scott shewbridgeraurscorp.com and juan perri@urscorp.com

${ }^{2}$ URS Corporation, 2870 Gateway Oaks Drive, Suite 150, Sacramento, CA, email: richard millet@urscorp.com, wilbur huang@urscorp.com and iuan vargas urscorp.com

3 Department of Water Resources, Division of Flood Management, 2825 Watt Avenue \#100, Sacramento, CA 95821, email: inamine (a)water.ca.gov and gmahnke(a)water.ca.gov

\section{ABSTRACT:}

A physical and mathematical model used in the third tier of the California Department of Water Resources' Urban Levee Geotechnical Evaluations Program Erosion Screening Process (ESP) is described. It has been developed and calibrated based on the results of Erosion Function Apparatus (EFA) test results of California river and levee soil samples, confirming the relationships relating general soil classification to erosion resistance as a function of water-induced shear stresses. The model is used to assess erosion during normal and/or flood conditions for combined wind and current loads. An example calculation using the method is provided.

\section{INTRODUCTION}

The California Department of Water Resources' Urban Levee Geotechnical Evaluations Program is evaluating urban levees in the Sacramento and San Joaquin river systems. As described in a companion paper, a three-tiered Erosion Screening Process (ESP) has been developed to qualitatively and quantitatively assess the risk of current and wind wave induced erosion failure on a levee's waterside slope. This paper describes the fluid and soil mechanics-based model developed for the quantitative third tier analyses.

\section{EROSION SCREENING PROCESS COMPUTATIONS METHODOLOGY}

To conduct the third tier quantitative analyses, an Erosion Screening Process (ESP) spreadsheet was developed to estimate the surface erosion potential on the waterside of a levee. It is a tool for use during screening level assessments of levee vulnerability; it is not a design tool. The ESP spreadsheet uses the same physical process model used to develop an erosion risk model for the US Army Corps of Engineers (URS, 2007).

In essence, the erosion potential assessment is conducted using six pieces of information: levee geometry, water/stream/river current characteristics, wind characteristics, armor characteristics, vegetation characteristics and soil type. Erosion 
risks to riverine levees will most likely be due to a weakened levee cross section coupled with high flow velocity and/or wave action. In large, open bodies of water like a bypass, wind-wave damage is expected to be a dominant cause of erosion. Erosion caused by factors like surface runoff, boat wakes, and embankment overtopping during a flood were not considered for this erosion analysis methodology.

\section{Erosion Rate Model}

Several erosion studies have been performed in the past that focus on identifying the erosion parameters and correlating those parameters to formulate an expression (i.e., a physical model) for erosion rates (Hanson and Temple, 2002, Hanson and Cook, 2004). The governing equation for this model is:

$$
\dot{\varepsilon}=\left(\mathrm{k}\left(\tau-\tau_{\mathrm{c}}\right)\right)>0
$$

where:

$\dot{\varepsilon}=$ erosion rate $(\mathrm{ft} / \mathrm{hr})$

$\mathrm{k}=$ erodibility coefficient or detachment rate coefficient $\left(\mathrm{ft}^{3} / \mathrm{lb}-\mathrm{hr}\right)$

$\tau=$ effective hydraulic stress on the soil boundary (psf)

$\tau_{c}=$ critical shear stress (psf) i.e., the shear stress at which erosion starts

The erosion rate $(\dot{\varepsilon})$ is a function of both hydraulic $(\tau)$ and geotechnical $(\mathrm{k}$, $\tau_{c}$ ) parameters. $\tau$ mainly depends on characteristics of water-soil boundary, current/stream velocity and/or wind wave height and period. Both $\mathrm{k}$ and $\tau_{\mathrm{c}}$ are functions of the engineering properties of the levee and the foundation materials.

The following subsections describe the hydraulic and geotechnical parameters in the above model and how they are used and modeled in the spreadsheet.

\section{Hydraulic Loading}

Two general types of erosion that are common for levees are current erosion (sometimes called scour) and wave erosion. In the erosion calculation, the shear stresses associated with each are calculated separately to estimate the combined erosion rate.

\section{Current/Stream Velocity Erosion Parameters}

The estimation of erosion rate due to shear stresses imparted to the levee and its foundation due to current/stream velocity requires information on the hydraulic parameters of stream velocity and water-soil interface roughness. Using the conventional assumption of a logarithmic velocity profile (USACE, 1994), the average hydraulic shear stress due to currents $\left(\tau_{\mathrm{s}}\right)$ can be calculated using Equation 2 .

$$
\tau_{\mathrm{s}}=1 / 2 \rho f_{\mathrm{c}} \mathrm{V}^{2}
$$

Where:

$\rho=$ mass density of water $\left(\mathrm{lbm} / \mathrm{ft}^{3}\right)$

$f_{c}=$ current friction factor (also referred to as the Fanning friction factor which is dimensionless $)=2\left(2.5\left(\ln \left(30 \mathrm{~h} / \mathrm{k}_{\mathrm{b}}\right)-1\right)\right)^{-2}$

(Danish Hydraulic Institute (DHI), 2007) 
where:

$$
\begin{aligned}
& \qquad \mathrm{h}=\text { water depth }(\mathrm{ft}) \\
& \mathrm{k}_{\mathrm{b}}=\text { bed roughness }(\mathrm{ft}) \\
& \mathrm{V}=\text { current speed }(\mathrm{ft} / \mathrm{s})
\end{aligned}
$$

\section{Wind Wave Erosion Parameters}

Erosion by waves can occur from two mechanisms; by generating excess shear stress on the soil underneath the waves (i.e., bottom currents) or by wave breaking on the levee slope. The estimation of the wave induced erosion rate requires estimates of wave height and period.

\section{Wave Height and Period}

Wind waves are generated by wind blowing over water and their height and period are a function of the wind speed, duration, water depth and fetch length. For the erosion spreadsheet it was assumed that the wind blows for sufficient duration for fully developed waves to form in deep water, making wave height and period a function of fetch length and wind speed only, a reasonable assumption for a screening-level assessment.

The waves generated by the wind are not all the same size or have the same period, so a spectra of values are generated. Typically a value of wave height is picked to represent the spectra called the significant wave height. Traditionally, the significant wave height is calculated as the average of one-third of the highest wave heights measured from the troughs to the peaks. Using this definition of significant wave height, the wave height can be estimated using the equations below (USACE, 1984, often referred to as SPM - The Shore Protection Manual):

$$
\begin{aligned}
& \frac{g H_{s}}{U_{A}^{2}}=1.6 \cdot 10^{-3}\left(\frac{g F}{U_{A}^{2}}\right)^{1 / 2}<2.433 \cdot 10^{-1} \\
& \frac{g T_{m}}{U_{A}}=2.857 \times 10^{-1}\left(\frac{g F}{U_{A}^{2}}\right)^{\frac{1}{3}}<8.134
\end{aligned}
$$

where,

$$
\begin{aligned}
& \mathrm{H}_{\mathrm{s}}=\text { significant wave height }(\mathrm{ft}) \\
& \mathrm{T}_{\mathrm{m}}=\text { average period of the wave }(\mathrm{s}) \\
& \mathrm{F}=\text { fetch length }(\mathrm{ft}) \\
& \mathrm{U}_{\mathrm{A}}=\text { the wind-stress factor }(\mathrm{ft} / \mathrm{s}) \\
& \quad \mathrm{U}_{\mathrm{A}}=2.329(0.447 \mathrm{U})^{1.23}(\mathrm{ft} / \mathrm{s}) \\
& \quad \text { where, } \mathrm{U}=\text { wind speed in miles } / \text { hour } \\
& \mathrm{g}=\text { acceleration due to gravity }\left(32.2 \mathrm{ft} / \mathrm{s}^{2}\right)
\end{aligned}
$$

The wave height is limted to approximately 60 percent of the water depth. Therefore in the spreadsheet if $\mathrm{H}_{\mathrm{s}}$ is greater than the 0.6 times the water depth, then it is set equal to 0.6 times the water depth. 
Hydraulic Shear Stress Due to Waves

The wind-driven waves will generate bottom currents with a corresponding shear stress. If this shear stress exceeds the critical shear stress of the soil, erosion will occur. The bottom current shear stress $\left(\tau_{\mathrm{w}}\right)$ can be estimated from Equation 5 below.

$$
\tau_{\mathrm{w}}=1 / 2 \rho \mathrm{f}_{\mathrm{w}} \mathrm{U}_{\mathrm{b}}^{2}
$$

where:

$\rho=$ mass density of water $\left(\mathrm{lbm} / \mathrm{ft}^{3}\right)$

$\mathrm{f}_{\mathrm{w}}=$ wave friction factor (Fanning - dimensionless)

$=\exp \left(5.213\left(\frac{a}{k_{l}}\right)^{-0.194}-5.977\right) \quad($ Swart, 1974)

if $\quad \frac{a}{k_{l}} \leq 1, \quad f_{w}=0.47$

$\mathrm{k}_{\mathrm{l}}=$ levee slope roughness $(\mathrm{ft})$

$\mathrm{a}=$ horizontal mean wave orbital motion at the bed (ft) (DHI, 2007)

$$
a=\frac{H}{\pi} \frac{1}{\sinh \left(\frac{2 \pi h}{L}\right)}
$$

$\mathrm{L}=$ wave length $(\mathrm{ft})$

$$
L=\frac{g T^{2}}{2 \pi}\left\{\tanh \left[\left(\frac{2 \pi}{T} \sqrt{\frac{h}{g}}\right)^{3 / 2}\right]\right\}^{2 / 3}
$$

$\mathrm{h}=$ water depth $(\mathrm{ft})$

$\mathrm{U}_{\mathrm{b}}=$ horizontal mean orbital wave velocity at water-soil interface $(\mathrm{ft} / \mathrm{sec})$

$\mathrm{H}=$ wave height $(\mathrm{ft})$

$$
U_{b}=\frac{2 H}{T} \frac{1}{\sinh \left(\frac{2 \pi h}{L}\right)}
$$

For levee erosion calculations, $\mathrm{H}=\mathrm{H}_{\mathrm{s}}$ and $\mathrm{T}=\mathrm{T}_{\mathrm{m}}$

The orbital wave velocity, $\mathrm{U}_{\mathrm{b}}$, is dependent on the significant wave height, the wave period, and the water depth. The roughness, $\mathrm{k}_{\mathrm{l}}$, is often related to some measure of the grain size of the slope (i.e., levee or foundation) materials. Puleo and Holland (2001) provide a summary of common relationships used to define $\mathrm{k}_{1}$.

\section{Shear Stress Due to Wave Breaking}

The science of estimating the shear stress on a levee due to wave breaking is much less advanced than the estimation of shear stress due to wave orbital velocities. To provide an estimate of the shear stress, the following assumptions are made:

- The rate of energy dissipation due to wave breaking can be estimated as a shear stress $(\tau)$ times a velocity, where the shear stress is the force per unit area on the levee surface due to the wave breaking, and the velocity is the rate 
at which energy is conveyed to the levee by the waves. The velocity at which energy is propagated is called the group wave speed and is represented by $c_{g}$. The rate of energy dissipation is then:

Rate of energy dissipation $=\tau \cdot c_{\mathrm{g}}$

The rate of energy dissipation is assessed in units of $1 \mathrm{bs}-\mathrm{ft}$ per feet ${ }^{2}$ per second (a more familiar unit may be BTU or calorie per $\mathrm{ft}^{2}$ per second)

- Only a portion of the wave energy dissipated by the wave breaking causes sediment erosion due to bed shear stress. That portion (i.e., the efficiency) is considered low because most of the wave energy is lost in the generation of turbulence.

Energy dissipation in the surf zone can be estimated from Equation 11 (Zou, Bowen and Hay, 2006):

$$
\Delta=\frac{1}{4} \rho g f \frac{\left(B H_{\max }\right)^{3}}{h}
$$

Where: $\Delta=$ energy dissipation rate $\left(\mathrm{lbf}-\mathrm{ft} / \mathrm{ft}^{2} / \mathrm{s}\right)$

$\rho=$ density of water $\left(\mathrm{lbm} / \mathrm{ft}^{3}\right)$

$\mathrm{g}=$ gravitational acceleration $\left(\mathrm{ft} / \mathrm{s}^{2}\right)$

$\mathrm{f}=$ wave frequency $(1 / \mathrm{s})$

$=1 / T_{p}$

$\mathrm{T}_{\mathrm{p}}=$ wave period ( $\mathrm{s}$ )

$\mathrm{B}=$ empirical coefficient often set equal to one

$\mathrm{H}_{\max }=$ wave height at breaking $(\mathrm{ft})$

$\mathrm{h}=$ local water depth (ft)

This form is similar to the form presented by USACE (2003), Lim and Chan (2003), and others.

$\mathrm{H}_{\max }$, the wave height at breaking can be estimated from:

$$
H_{\max }=\frac{0.88}{k} \tanh \left(\gamma_{b} \frac{k h}{0.88}\right)
$$

Simplified to approximately:

$$
H_{\text {max }}=0.14 \cdot L \cdot \tanh \left(\frac{2 \pi \cdot h}{L}\right)
$$

Where: $\quad \mathrm{k}=$ wave number $=2 \pi / \mathrm{L}\left(\mathrm{ft}^{-1}\right)$

$\gamma_{\mathrm{b}}=$ ratio between wave height and water depth in shallow water (depthlimited breaking) and can vary from 0.4 to 1.2 (Zou et al. 2006) but is typically taken to be 0.78 (Larson and Kraus, 2000). A value of 0.78 is used in this analysis.

$\mathrm{h}=$ local water depth (ft)

To estimate the shear stress due to wave breaking it is necessary to estimate the group velocity. The group velocity, $\mathrm{c}_{\mathrm{g}}$, can be estimated as (Kinsman, 1984): 


$$
c_{g}=0.5 \cdot \sqrt{\frac{g}{k} \tanh \left(2 \pi \frac{h}{L}\right)} \cdot\left(1+\frac{2 k h}{\sinh (2 k h)}\right)
$$

In most scenarios Equation 3-20 can be simplified assuming deep water (i.e., $\mathrm{h} / \mathrm{L}>\sim 0.5$ ) to:

$$
c_{g d}^{2}=\frac{g \cdot L}{8 \pi}
$$

The shear stress is then estimated as:

$$
\tau=\varepsilon \Delta / c_{g}
$$

Where

$\varepsilon=$ portion of the energy dissipated by wave breaking that is dissipated as bed shear stress.

To estimate wave energy bed shear stress dissipation rates, a limited number of case histories were evaluated during testing of a similar erosion evaluation tool developed for the United States Army Corps of Engineers (URS, 2007). Based on those limited results, energy dissipated as bed shear stress appears to be between 5 and 10 percent. Therefore, the analyses performed for the DWR ULE program used an estimated wave breaking bed shear stress dissipation value of 7.5 percent.

Additional work in this area seems warranted.

\section{Geotechnical Parameters}

Once the hydraulic stress on the levee material due to either the stream velocity or wind generated waves is known, the next step is the estimation of the geotechnical parameters that influence the erosion potential (erosion rate) of a levee.

\section{Armoring and Vegetation}

Physical armoring and vegetation have both been observed to have an impact on the initiation and continuation of erosion of levee slopes. The erosion calculation uses four generic categories: presence and absence of armoring and presence and absence of vegetation. Depending on the presence or absence of either, and the design critical armor/vegetation velocity and critical armor/vegetation wave height, the erosion rate computed using Equation 1 is modified. If armoring and or vegetation is present, and the flow velocity does not exceed either critical velocity, and the wave height does not exceed either critical wave height then, zero erosion is computed. If armoring or vegetation is present, but the flow velocity associated with an analyzed flood level (i.e., water surface elevation) exceeds either critical velocity, or if the wave heights exceed the critical wave heights, the armor and or vegetation is considered eroded and Equation 1 is used to calculate erosion.

Special note - armor and vegetation erosion resistance is a significant factor in the analyses, but due to space limitations, cannot be more fully discussed in this paper. The "Erosion Toolbox: Levee Risk Assessment Methodology" (URS, 2007) can be consulted for additional information and discussion regarding armor-types and vegetation classes and associated modeling parameters. 


\section{Levee and Foundation Materials}

The characteristics of the levee and foundation materials have a significant impact on the expected erosion rates. Typically, dense coarse-grained materials and stiff fine-grained materials are generally more resistant to erosion than loose coarsegrained materials and soft fine-grained materials, respectively. Therefore, it is important to identify the levee and foundation materials and classify them appropriately. The calculation incorporated five main soil types, generally categorized under ASTM D 2488 (Standard Practice for Description and Identification of Soils) as boulders and cobbles (very resistant), gravel (resistant), sand (erodible), silt (very erodible) and clay (moderately resistant). Note, clays and silts are not differentiated based on particle size alone, but rather by limiting percentage of a maximum particle size and plasticity characteristics.

\section{Critical Shear Stress as a Function of Soil Type}

Erosion rates as a function of flow velocity / induced shear stress can be measured in the laboratory using one of several devices such as the Erosion Function Apparatus (EFA, Briaud et. al, 2001a and b). The critical shear stress, $\tau_{\mathrm{c}}$, is defined as the shear stress corresponding to a rate of erosion of $1 \mathrm{~mm} / \mathrm{hr}$ in the EFA. While useful for analytical studies, this method is impractical for rapid surveys.

Alternatively, the critical shear stress can be estimated using empirical correlations between the critical shear stress and soil index properties. Several empirical correlations between critical shear stress $\left(\tau_{c}\right)$ and soil index properties such as grain size, plasticity index and shear strength are available in the literature to estimate the value of $\tau_{\mathrm{c}}$ (URS, 2007). In order to simplify the analyses, erosion resistance of the levee and foundation material has been divided into five broad classes related to their ASTM classifications, as shown in Table 1. The erosion calculations used these typical values for critical shear. The values shown are based on the experimental and field-testing results as reported by Briaud et al. (2001a, 2003) and Hanson and Simon (2001).

\section{Erodibility Coefficient as a Function of Soil Type}

One method to estimate the coefficient of erodibility, $\mathrm{k}$, used in Equation 1, is by performing the jet index test (ASTM D 5852). However performing site-specific tests will be impractical for rapid assessment of conditions. Therefore, in a manner similar to the method used to evaluate critical shear stresses, to simplify the analyses, erodibility of the levee and foundation materials has been divided into five broad classes related to the material's ASTM classification, as shown in Table 1. The erosion calculations used typical values for erodibility coefficients. The values presented in Table 1 are based on the experimental and field-testing results as reported by Briaud et. al (2001a, 2003) and Hanson and Simon (2001). 
Table 1 - Typical Values for Critical Shear Stress and Coefficient of Erodibility of Soils

\begin{tabular}{|l|l|c|c|}
\hline $\begin{array}{c}\text { Levee/Foundation } \\
\text { Material }\end{array}$ & \multicolumn{1}{|c|}{$\begin{array}{c}\text { ASTM Typical } \\
\text { Soil Types }\end{array}$} & $\begin{array}{c}\text { Critical } \\
\text { Shear } \\
\text { Stress, } \tau_{\mathbf{c}} \\
(\mathbf{p s f})\end{array}$ & $\begin{array}{c}\text { Erodibility } \\
\text { Coefficient, } \\
\mathbf{k} \\
\left(\mathbf{f t}^{3} / \mathbf{l b}-\mathbf{h r}\right)\end{array}$ \\
\hline Very Resistant & BOULDERS and COBBLES & 4.869 & 0.005 \\
\hline Resistant & GRAVEL (GP-GW) & 1.058 & 0.021 \\
\hline Moderately Resistant & CLAY (CL, CH, SC, GC) & 0.094 & 0.094 \\
\hline Erodible & SAND (SP, SM and mixtures) & 0.014 & 0.409 \\
\hline Very Erodible & SILT (ML) & 0.003 & 1.867 \\
\hline
\end{tabular}

\section{Levee Geometry}

Figure 1 illustrates the geometric characteristics of a given levee that influence the erosion analyses. Erosion of the foundation and/or levee waterside slope materials is considered in the analysis. For the DWR studies, overtopping is considered as a separate failure mode. Erosion due to overtopping is not evaluated in this process, though the soil-water model used in this analysis can be expanded for such analyses.

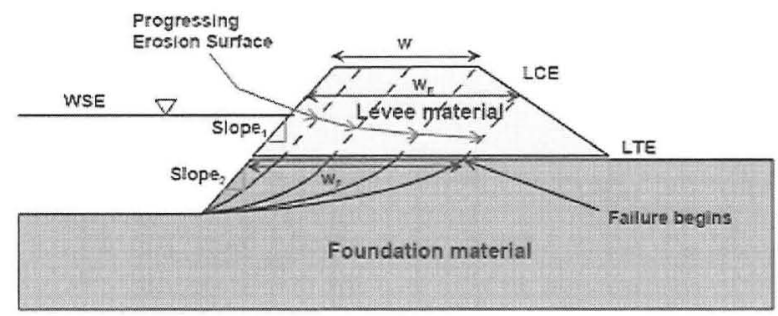

Notes:
) LCE: Maximum water surtace or ievee crest elevation
LTE: Landsode toe elevaton
WSE: Water surface elevalion
w. Levee crest width
w: Elfeclive levee width
Wr: Width of levee at the LTE that must be eroded for failure to occur
For rallure to occur. WSE must be greater than LTE

Figure 1 - Levee and Foundation Geometry

\section{CALIBRATION TESTING}

To validate the soil type categorizations of critical shear stress and erodibility coefficients (i.e., Table 1), soil samples were collected throughout the DWR ULE study areas. Soil Characterization tests, including gradation, Atterberg limits, moisture contents and density tests were performed on the samples. These samples were then tested in an Erosion Function Apparatus or EFA (Figure 2, Briaud et al., 2001a). The $75 \mathrm{~mm}$ outside diameter sampling tube is placed through the bottom of the conduit where water flows at a constant velocity. The soil is pushed out of the 
sampling tube only as fast as it is eroded by the water flowing over it. For each velocity, an erosion rate is measured and a shear stress is calculated.
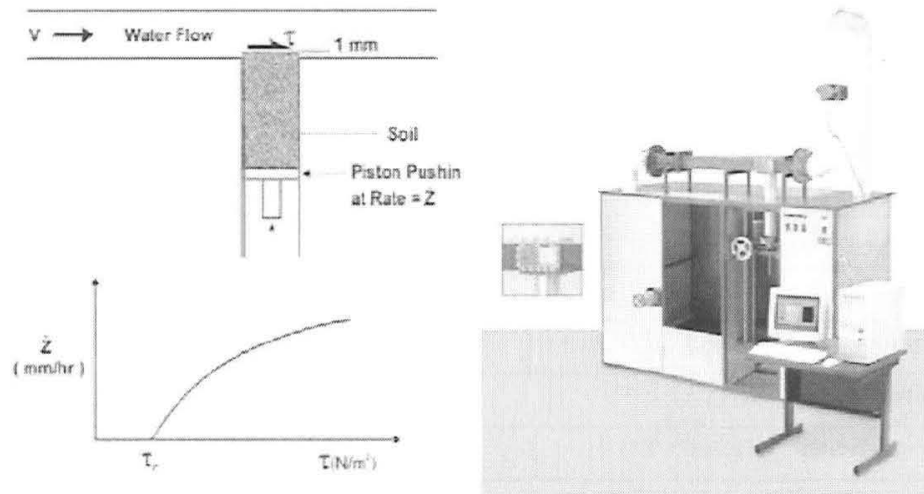

Figure 2 - Erosion Function Apparatus (Briaud et al, 2001a)

Figure 3 presents the results of the EFA tests. These are compared with the estimated erosion rates based on the theoretical models and parameters described above in Table 1, showing excellent agreement for the silt and clay materials tested.

Erosion Rate vs. Shear Stress
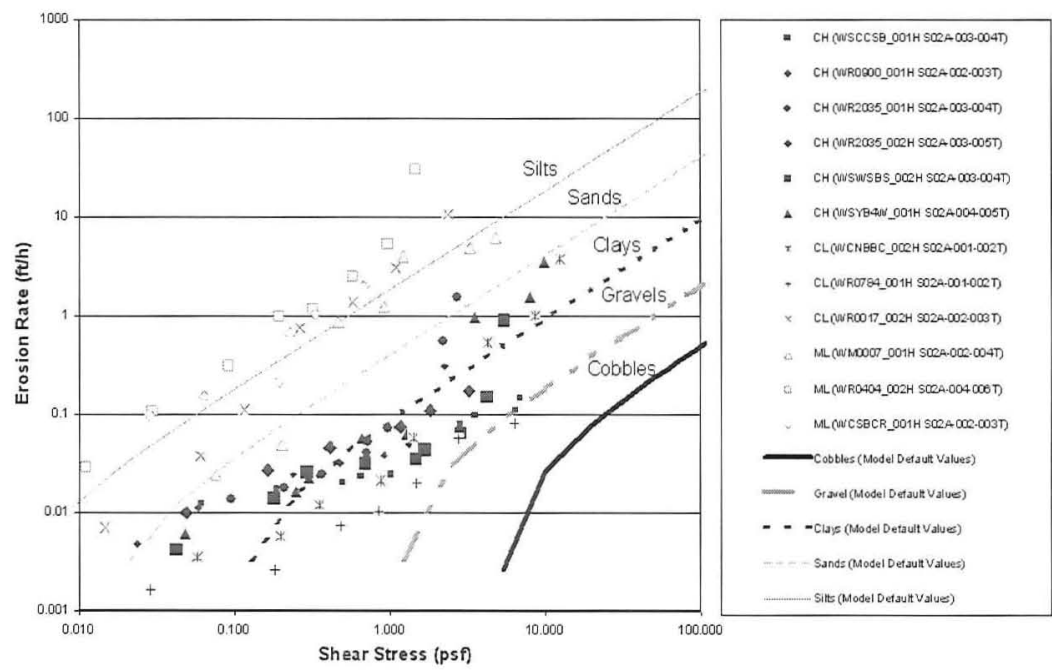

Figure 3 - EFA Testing Results 


\section{EXAMPLE CALCULATION}

To demonstrate the application of the methodology, the following example calculation is provided. The river current and wind loading are summarized in Table 2 and levee conditions are summarized in Table 3.

Table 2 - River Current and Wind Wave Loading

\begin{tabular}{|l|c|c|}
\hline Factor & \multicolumn{2}{|c|}{ Hydrograph Stage } \\
\hline Water/Stream/River Current & 1 st & 2nd \\
\hline Water Surface Elevation, NAVD 88 (ft) = & 15 & 10 \\
\hline Velocity, V (ft/sec) = & 3.2 & 1 \\
\hline Duration for Velocity, d (hours) = & 100 & 2000 \\
\hline Wind/Wave & 1 st & $2 \mathrm{nd}$ \\
\hline Wind Speed, U' (miles/hr) = & 50 & 50 \\
\hline Duration of Wind (hrs) $=$ & 2 & 2 \\
\hline Maximum fetch length (ft), F = & 60000 & 60000 \\
\hline Efficiency of wave breaking to erode sediments $=$ & $7.50 \%$ & $7.50 \%$ \\
\hline
\end{tabular}

Table 3 - Levee Conditions (geometry, soils, armor and vegetation)

\begin{tabular}{|c|c|}
\hline Geometry & \\
\hline Channel bottom elevation, NAVD $88(\mathrm{ft})=$ & 0 \\
\hline Landside toe elevation, NAVD $88(\mathrm{ft}), \mathrm{LTE}=$ & 8 \\
\hline Levee slope $(\mathrm{X}$ Horizontal to 1 Vertical; Specify X) $=$ & 4 \\
\hline Effective levee width against erosion (ft) & 40 \\
\hline \multicolumn{2}{|l|}{ Soil Type } \\
\hline Levee and Foundation Soil Type & Sand - Erodible \\
\hline Critical Shear Stress (psf), $\tau_{\mathrm{c}}=$ & 0.0136 \\
\hline Erodibility Coefficient ( $\left.\mathrm{ft}^{\wedge} 3 / \mathrm{lb}-\mathrm{hr}\right), \mathrm{k}=$ & 0.4093 \\
\hline Levee slope roughness $(\mathrm{ft}), \mathrm{K}_{\mathrm{L}}=$ & 0.0197 \\
\hline Slope of Erosion Rate vs Velocity line, $\mathrm{m}_{\log -\log }=$ & 6.9 \\
\hline Velocity for which Erosion Rate is $1 \mathrm{ft} / \mathrm{h}(\mathrm{ft} / \mathrm{s}), \mathrm{V}_{1}=$ & 4.6 \\
\hline Armor /Vegetation & $\mathrm{No} / \mathrm{Yes}$ \\
\hline Velocity at which vegetation protection is lost $(\mathrm{ft} / \mathrm{s})=$ & 3 \\
\hline Wave height at which vegetation protection is lost $(\mathrm{ft})=$ & 5 \\
\hline
\end{tabular}


The loading and estimated erosion for current and wind for the first and second stages is presented on Figure 4.

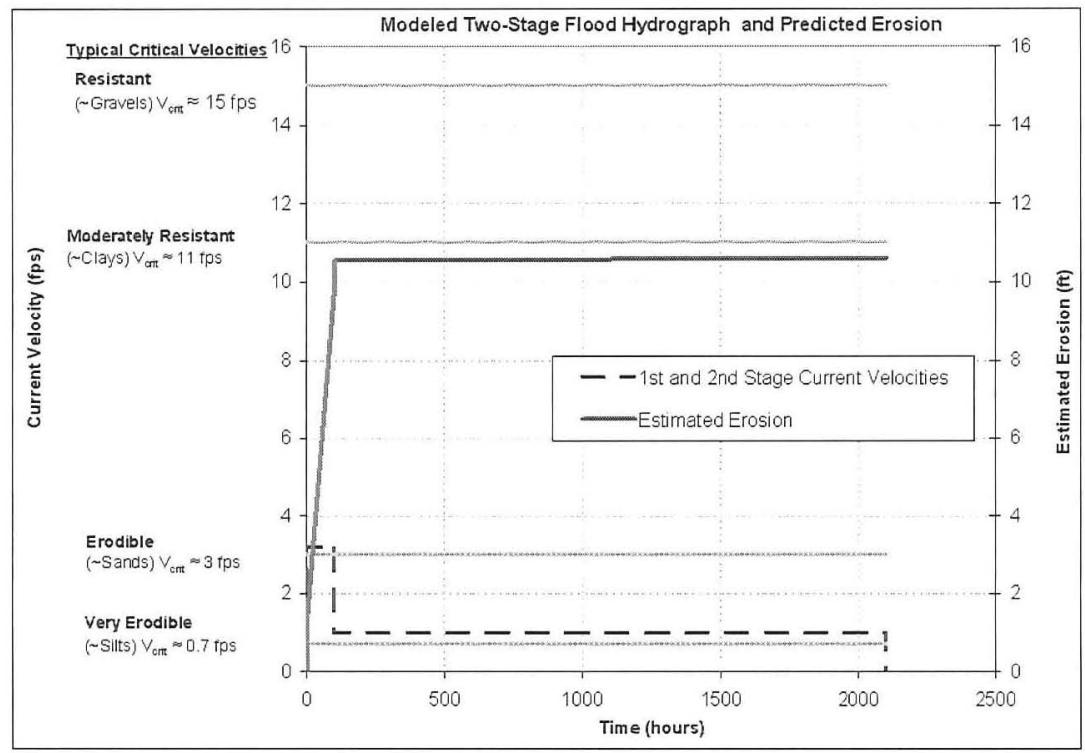

Figure 4 - Typical Erosion Evaluation Results for Two Stage Hydrograph

Wave erosion for stage 1 and stage 2 is estimated at 1.5 and 0.9 feet, respectively. Because estimated wave heights during stage 1 were greater than the wave heights that the vegetation could withstand, vegetation was lost during the beginning of stage 1 and provided no protection for the levee and foundation slopes during wind or current loadings for stage 1 or stage 2. Current erosion for stage 1 and stage 2 are estimated at 8.2 and $<0.1$ feet respectively. Current erosion for stage 2 is low because the current velocity is less than the critical velocity for the levee and foundation materials. Total erosion is estimated to be 10.6 feet, which is less than the levee width (40 feet), but it is substantial, nevertheless. In this study, if estimated erosion is greater than $25 \%$ of the foundation or embankment width, then the site is considered to have High erosion potential.

\section{CONCLUSION}

Using theoretical models combined with soils testing results, a model to predict erosion on the waterside slopes has been developed and is being used to assess the erosion potential of the waterside slopes as part of a three tiered screening process for over 350 miles of levees in California. The results of these analyses will be used to help assess levee erosion vulnerability and potential mitigation prioritization. 


\section{REFERENCES}

Briaud, J.-L., Ting F., Chen, H.C., Cao Y., Han S. -W., Kwak K. 2001. Erosion Function Apparatus for Scour Rate Predictions. Journal of Geotechnical and Geoenvironmental Engineering. ASCE, Vol. 127, N. 2, pp. 105-113.

Briaud, J.-L., Chen, H.C., Li Y., Nurtjahyo, P., Wang, J. 2003. Complex Pier Scour and Contraction Scour in Cohesive Soils. National Cooperative Highway Research Program Report.

Danish Hydraulic Institute (DHI). 2007. Mike 21 Flow Model. Mud Transport Module, Scientific Background. DHI, Denmark.

Hanson, G.J., Simon, A. 2001. Erodibility of Cohesive Streambeds in the Loess Area of the Midwestern USA. Hydrological Processes. Vol. 15 No 1. pp. 23-38.

Hanson, G.H., Temple, D.M. 2001. Performance of Bare-Earth and Vegetated Steep Channels Under Long-Duration Flows. Presented at the 2001 ASAE Annual Meeting. ASAE Paper No. 012157.

Hanson, G.J., Cook, KR. 2004. Apparatus, Test Procedures, and Analytical Methods to Measure Soil Erodibility in Situ. Applied Engineering in Agriculture. American Society of Agricultural Engineers, Vol. 20, No. 4, pp. 455-462.

Larson, M., Kraus, N. 2000. Enhancements of the Numerical Model of the Longshore Current NMLONG to Include Interaction Between Currents and Waves (NMLong-CW). United States Army Corps of Engineers. ERDC/CHL CETNIV-25.

Swart, D.H. 1974. Offshore Sediment Transport and Equilibrium Beach Profiles. Delft Hydraulic Lab. Publication 131. Delft University. Delft. 302 pp.

United States Army Corps of Engineers. 1994. Hydraulic Design of Flood Control Channels. EM 1110-2-1601. June 30.

United States Army Corps of Engineers. 1984. Shore Protection Manual, $4^{\text {th }}$ Ed., 2 vol. United States Army Corps of Engineers Waterways Experiment Station. U.S. Government Printing Office. Washington DC.

United States Army Corps of Engineers. 2006. Coastal Engineering Manual (CEM). United States Army Corps of Engineers. Waterways Experiment Station. EM 1110-2-1100.

URS. 2007. Erosion Toolbox: Levee Risk Assessment Methodology: Users Manual. Report prepared for the United States Army Corps of Engineers. December. 